\title{
Formulasi Pangan Fungsional Tinggi Kalori Tinggi Protein: Biskuit Ubi Jalar-Ikan Gabus (Big@Bus)
}

\author{
Cicilia Windiyaningsih, Yeny Sulistyowati, Yeni Ariestanti \\ Universitas Respati Indonesia \\ Email: yeny.sulistyowati@urindo.ac.id
}

\begin{abstract}
ABSTRAK
Peningkatan kasus TB merupakan tantangan bagi tenaga kesehatan dan sektor terkait dalam pencegahan dan penanganan TB secara terpadu dan komprehensif. Propinsi DKI di urutan kedua teratas di Indonesia. Perkembangan penanggulangan TB belum menggembirakan dan permasalahan TB masih belum dapat diselesaikan. Dalam menangani permasalahan untuk penderita TB, selain istirahat dan obat, diperlukan diet yang sehat dan tepat untuk membantu pemulihan penderita TB. Dietnya adalah Diet Tinggi Kalori Tinggi Protein. Sumber protein hewani yang memiliki potensi besar adalah ikan gabus (Ophiocephalus striatus). Selain sumber makanan tinggi protein, diet yang diharapkan bisa mempercepat proses penyembuhan TB dengan diet tinggi kalori. Dari kelompok umbi-umbian, ada ubi jalar yang berasa manis, mengandung karbohidrat kompleks disertai vitamin dan mineral yang mudah dicerna. Makanan tambahan berbasis pangan lokal yaitu biskuit dengan suplementasi tepung ikan gabus dan ubi jalar dapat menjadi pilihan sebagai PMT Pemulihan TB. Dalam penelitian ini metode yang digunakan adalah metode eksperimen. Pelaksanaan penelitian adalah formulasi biskuit ikan gabus dengan penambahan tepung ubi jalar (Formula Pangan BIG@BUS). Hasil uji organoleptik oleh panelis diketahui bahwa warna dari tepung dan rasa dari biskuit mendapatkan rata-rata tertinggi dari penilaian panelis. Sedangkan aroma tepung dan tekstur dari biskuit mendapatkan nilai rerata terendah dari panelis. Hasil pemeriksaan kandungan zat gizi pemeriksaan untuk tepung menjadi biskuit terjadi penurunan kadar zat gizi karena perubahan bentuk dan proses pengolahannya, kecuali kadar Lemak.
\end{abstract}

Kata Kunci: Ikan Gabus, Ubi, TB

\section{ABSTRACT}

The increase in TB cases is a challenge for health workers and related sectors in the prevention and treatment of TB in an integrated and comprehensive manner. DKI Province is in the second highest rank in Indonesia. The development of TB control has not been encouraging and the TB problem has not been resolved. In dealing with problems for people with TB, in addition to rest and medication, a healthy and proper diet is needed to help recover TB sufferers. The diet is a High Calorie High Protein Diet. Source of animal protein that has great potential is snakehead fish (Ophiocephalus striatus). In addition to high-protein food sources, the diet is expected to accelerate the TB healing process with a high-calorie diet. From the tubers group, there is sweet potato which tastes sweet, contains complex carbohydrates accompanied by easily digestible vitamins and minerals. Supplementary food based on local food, namely biscuits with snakehead fish meal and sweet potato supplementation, can be an option as PMT for TB recovery. In this study the method used is the experimental method. The implementation of the research is the formulation of snakehead fish biscuits with the addition of sweet potato flour (Food Formula BIG@BUS). The results of the organoleptic test by the panelists showed that the color of the flour and the taste of the biscuits got the highest average from the panelists' assessment. While the flour aroma and texture of the biscuits got the lowest average value from the panelists. The results of the examination of the 
nutritional content of the examination for flour into biscuits showed a decrease in the levels of nutrients due to changes in the shape and processing process, except for the fat content.

Keywords: Cork Fish, Sweet Potato

\section{PENDAHULUAN}

\section{LATAR BELAKANG}

Tuberkulosis (TB) masih menjadi masalah kesehatan di seluruh dunia. Beban TB semakin meningkat seiring dengan semakin bertambahnya kasus koinfeksi TB-HIV. Pada tahun 2013, diperkirakan insiden tuberkulosis secara global mencapai 9 juta $^{1}$. Jumlah penderita TB paru di Indonesia terus meningkat, terdapat 460.000 kasus baru TB dengan jumlah kematian sebesar 62.246 orang $^{2}$. Kematian akibat TB pada sebagian besar negara di dunia, lebih banyak pada pria daripada wanita. Dampak TB pada wanita lebih besar secara ekonomi dan reproduksi, serta terhadap anak dan anggota keluarga yang lain ${ }^{3}$.

Propinsi DKI menduduki urutan kedua teratas di Indonesia. Dalam penyelesaian masalah yang komprehensif maka perlu dilihat sisi demografi, pedesaan dan perkotaan. Untuk wilayah Jawa Timur, Kabupaten Mojokerto ${ }^{4}$, menjadi wilayah yang sesuai untuk keterwakilan lokasi pedesaan dan Jakarta Timur ${ }^{5}$ di Propinsi DKI menjadi model untuk wilayah perkotaan. Perkembangan penanggulangan TB belum menggembirakan dan permasalahan TB masih belum dapat diselesaikan. Penyebab utama diantaranya, masalah kemiskinan, pertumbuhan ekonomi, beban determinan sosial yang berat. Salah satu masalah yang dihadapi program TB nasional dalam melakukan akselerasi dan ekspansi program adalah kurang sumber dava manusia, subyek dari program, baik menyangkut kualitas maupun kuantitas. Upaya dalam kerangka ekspansi DOTS, peningkatan sumber daya manusia menjadi cukup sentral dan prioritas sebagai upava investasi yang tepat dan biaya efektif untuk mencapai target global. Persoalan jangka 
panjang adalah keberlangsungan program, tanpa keterlibatan semua sektor terkait, TB di Indonesia akan tetap menjadi persoalan kesehatan masyarakat yang besar Selain dukungan SDM model edukasi TB di masyarakat juga memegang peranan sangat penting ${ }^{6}$. Untuk wilayah perkotaan dan pedesaan tentunya memiliki karakteristik yang berbeda, sehingga perlu diterapkan model edukasi yang sesuai.

Dalam menangani permasalahan yang ada perlu diperhatikan kembali beberapa gejala TB. Gejala potensi TB termasuk kelenjar bengkak, kesulitan bernafas, penurunan BB, batuk, demam dan menggigil. Selain istirahat dan obat yang biasa diberikan diperlukan diet yang sehat dan tepat untuk membantu meningkatkan pemulihan bagi seorang penderita TB. Diet yang biasa diberikan adalah Diet yang Tinggi Kalori Tinggi Protein. Sumber protein hewani yang memiliki potensi besar adalah ikan gabus (Ophiocephalus striatus). Ikan gabus merupakan bahan sumber albumin potensial, dapat digunakan sebagai bahan

sumber biofarma dan bahan subtitusi albumin manusia ${ }^{7}$. Selain sumber makanan tinggi protein, diet yang diharapkan bisa mempercepat proses penyembuhan TB dengan diet tinggi kalori. Ada berbagai sumber kalori bisa menjadi alternatif, yaitu sumber Lemak maupun $\mathrm{KH}$ seperti beras, jagung dan umbi-umbian. Dari kelompok umbi-umbian, ada ubi jalar yang berasa manis, mengandung karbohidrat kompleks disertai vitamin dan mineral yang mudah dicerna. Untuk dapat memberikan manfaat yang lebih baik sebagai makanan fungsional maka protein dari ikan gabus dan karbohidrat dari ubi diformulasikan menjadi bentuk yang bisa diterima penderita TB dan dapat dikonsumsi dalam waktu yang lama, sehingga perlu diolah menjadi bentuk lain yaitu biskuit. Makanan tambahan berbasis pangan lokal yaitu biskuit dengan suplementasi tepung ikan gabus dan ubi jalar dapat menjadi pilihan sebagai PMT Pemulihan TB. 


\section{METODE PENELITIAN}

Penelitian ini dilaksanakan pada bulan Januari hingga Nopember 2019. Tempat penelitian di Jakarta Timur Propinsi DKI untuk pembuatan Formula Biskuit Ubi jalar dan ikan gabus. Lokasi penelitian untuk formulasi BIG@BUS di di Lab. Pengolahan Pangan, analisis zat gizi tepung ikan gabus dan tepung ubi serta biskuit di BPOM DKI Jakarta.

Bahan utama penelitian eksperimen formulasi BIG@BUS adalah ikan gabus segar dan ubi jalar, pengolahan tepung ikan dan tepung ubi jalar menggunakan alat antara lain oven dan blender tepung.

Formulasi biskuit berbasis tepung ikan gabus dan tepung ubi menggunakan rancangan percobaan RAL (Rancangan Acak Lengkap) dengan empat taraf perlakuan, yaitu $0 \%, 10 \%, 15 \%$, dan $20 \%$ tepung ikan dan tepung ubi dari berat total adonan biskuit. Penerimaan terhadap biskuit berbasis tepung ikan dan ubi menggunakan uji organoleptik berupa uji hedonik dengan panelis terlatih sebanyak 30 orang dan skala penilaian $1-5$.

\section{HASIL DAN PEMBAHASAN}

Pada tahap ini meliputi penelitian eksperimen laboratorium untuk mengembangkan produk Biskuit dari Ubi Jalar Ungu dan Ikan Gabus dengan melakukan uji sensoris (organoleptik), uji mikrobiologi dan keamanan pangan, dan analisis komposisi kimia.

$$
\text { Penelitian di lakukan di }
$$

Laboratorium Pangan Fakultas Pertanian Universitas Respati Indonesia untuk pembuatan Biskuit. Pengujian Ianjutan dilakukan di Balai Besar Pengawas Obat dan Makanan di Jakarta. Alamat Badan POM di Jl As Syafiiyah 133 Cilangkap Jakarta Timur 13870. Penelitian di Bulan Februari sampai dengan Maret 2019. Kemudian dilakukan studi pendahuluan untuk kelengkapan data dan penetapan data Penerima Hibah pada bulan April 2019. Kontrak penelitian ditandatangani pada tanggal 27 Mei 2019, serta surat 
Jurnal Ilmiah Respati

penugasan dengan No. bahwa Biskuit: Warna adalah Coklat, Aroma: 44/ST.LPPM/UNR/V/2019.

Proses pembuatan Biskuit, dimulai dengan proses penepungan Ubi Jalar Ungu dan Ikan Gabus, dimulai pada Bulan September 2019. Bahan didapatkan dari Pasar Munjul, dari tempat pembelian yang sama dan waktu pembelian yang sama. Kemudian setelah itu dilanjutkan dengan proses pembuatan biskuit Ubi Jalar Ungu dan Ikan Gabus.

\section{A. Hasil}

Berdasarkan hasil pengujian yang telah dilakukan pada tanggal 22 Oktober didapatkan hasil uji organoleptik dari BPOM

normal, Rasa: normal, tekstur: padat. Untuk tepung didaptkan hasil organoleptik Warna: Coklat, aroma: Normal, Rasa: normal, tektur: padat, serbuk halus. Uji organoleptik dengan metode test hedonik dilakukan untuk mengetahui pada tingkat kesukaan oleh konsumen tehadap 30 panelis. Analisa data penelitian ini yaitu analisis laboratorium berupa kandungan zat gizi makro (kadar lemak, dan kadar protein) dan mikro (Fe, Zn, B1 dan B2). Hasil penelitian tepung dan biskuit ubi jalar ungu dan ikan gabus berupa pengujian organoleptik dapat disajikan dalam bentuk Grafik 1 :

Tepung Biskuit

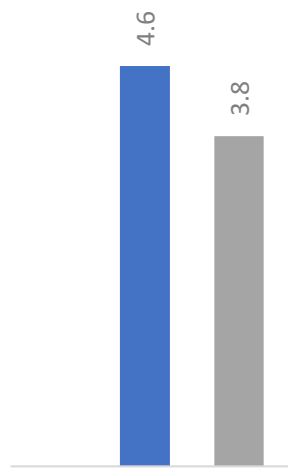

WARNA

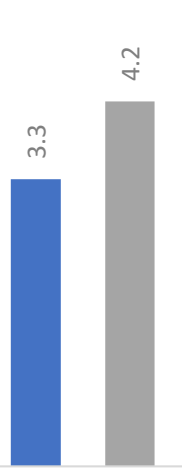

AROMA

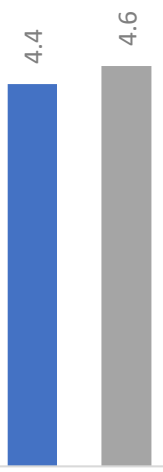

RASA

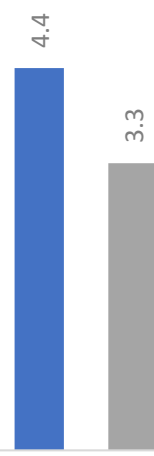

TEKSTUR 
Gambar 1. Grafik Rerata Penilaian Panelis terhadap Tepung dan Biskuit Ubi Jalar Ungu dan Ikan Gabus

Dari grafik tersebut dapat diketahui

bahwa Warna dari tepung dan rasa dari biskuit

mendapatkan rata-rata tertinggi dari penilaian panelis. Sedangkan aroma tepung dan tekstur dari biskuit mendapatkan nilai rerata terendah dari panelis.

Tabel 1. Nilai Kandungan Gizi Makro dan Mikro Biskuit Ubi Jalar Ungu dan Ikan Gabus

\begin{tabular}{lrr}
\hline & \multicolumn{1}{c}{ Tepung } & \multicolumn{1}{c}{ Biskuit } \\
\hline Kadar Lemak & $1,12 \%$ & $16,91 \%$ \\
Kadar Protein & $19,29 \%$ & $12,33 \%$ \\
Fe & $89,449 \mathrm{mg} / \mathrm{kgBB}$ & $30,267 \mathrm{mg} / \mathrm{kg}$ \\
Zn & $24,479 \mathrm{mg} / \mathrm{kg}$ & $16,017 \mathrm{mg} / \mathrm{kg}$ \\
B1 & $0,84 \mathrm{mg} / \mathrm{kg}$ & $0,47 \mathrm{mg} / \mathrm{kg}$ \\
B2 & $3,43 \mathrm{mg} / \mathrm{kg}$ & $2,01 \mathrm{mg} / \mathrm{kg}$ \\
\hline
\end{tabular}

Dari tabel diketahui bahwa hampir semua pemeriksaan untuk tepung menjadi biskuit terjadi penurunan kadar zat gizi karena

B. Pembahasan

Berdasarkan literatur

didapatkan hasil bahwa kandungan gizi ubi jalar ungu varie- tas antin-3 yaitu sebanyak $150,7 \mathrm{mg}$ an- tosianin, $1,1 \%$ serat, $18,2 \%$, pati, $0,4 \%$ gula reduksi, $0,6 \%$ protein, $0,70 \mathrm{mg}$ zat besi dan 20,1 mg vitamin C (Balitbangtan, perubahan bentuk dan proses pengolahannya, kecuali kadar Lemak.
2016). Senyawa antioksidan selain antosianin yang terdapat pada ubi jalar adalah vitamin C, vitamin E, lutein, zeaxanthin, dan betakaroten yang merupakan pasangan antioksidan karotenoid (Teow dkk (2007) dalam Husna dkk, 2013). Dari semua varietas warna umbi ubi jalar yang terdiri 
dari warna putih, kuning, oranye dan ungu. Hasil penelitian analisis vitamin $C$ pada varietas ubi jalar yang umbinya berwarna ungu memiliki kandungan vitamin C paling besar yaitu 0,0177 mg/100 gram (Nathania dkk, 2013).

Ikan gabus adalah ikan air tawar yang banyak ditemukan di Indonesia, secara uji klinis ikan gabus memiliki banyak manfaat yang baik khususnya bagi kesehatan tubuh manusia karena mengandung banyak kadar protein yang tinggi hinggamencapai 25,2\% b/b (Setiawan, 2013). Protein yang terdapat pada ikan gabus ini sangat penting bagi tubuh manusia karena dapat membantu adanya pertumbuhan, alat pengangkut dan sistem pergerakan (Winarno, 2008). Disamping itu ikan gabus memiliki kandungan albumin yang cukup tinggi, yang berguna untuk membantu proses penyembuhan luka pasca operasi (Setiawan, 2013).

Penelitian yang dilakukan oleh Fatmawati, dkk menghasilkan data bahwa tepung ikan gabus yang terbaik diperoleh dari perlakuan pengukusan dan ekstraksi lemak dengan kadar 7,46\%, dan kadar protein terlarut $10,88 \%$, dan kadar rendemen 15,79\%. Hasil uji organoleptik terhadap warna, kenampakan dan tekstur tepung ikan gabus, menunjukkan bahwa tepung ikan gabus yang dibuat dengan cara pengukusan dan ekstraksi lemak, merupakan tepung ikan gabus yang terbaik dari hasil penelitian.

Pemanfaatan tepung ikan gabus dalam campuran pembuatan biskuit, dimana kandungan utama ikan gabus adalah albumin yang berfungsi meningkatkan kadar albumin didalam darah juga membantu penyembuhan 
beberapa penyakit (Pangaribuan, 2013).

Dari data hasil Riskesdas (2013) ten- tang konsumsi makanan dari olahan tepung terigu diantaranya mi instan, mi basah, roti dan biskuit, sebanyak $13,4 \%$ penduduk In- donesia mengkonsumsi biskuit $\geq 1$ kali per hari. Ketergantungan masyarakat Indonesia terhadap tepung terigu sangat tinggi. Hal tersebut dapat dilihat dengan banyaknya produk olahan pangan yang menggunakan tepung terigu. Upaya diversifikasi pangan penting dilakukan, selain untuk mengurangi ketergantungan pada tepung terigu, juga untuk menggali potensi-potensi pangan lainnya (Yanuwardana dkk (2013) dalam Widyastuti, 2015).

Biskuit adalah produk yang diperoleh dengan memanggang adonan yang berasal dari tepung terigu dengan penamba- han makanan lain dan dengan atau penam- bahan bahan tambahan pangan yang diijinkan. Biskuit diklasifikasikan dalam em- pat jenis yaitu biskuit keras, crackers, cook- ies dan wafer (Badan Standardisasi Nasion- al, 2011).

Data asosiasi tahun 2012 konsumsi biskuit diperkirakan meningkat $55-85 \%$ didorong oleh kenaikan konsumsi domestik. Biskuit dikonsumsi oleh seluruh kalangan usia, baik bayi maupun dewasa mengkon- sumsi biskuit dengan jenis yang berbeda- beda (Sari, 2013).

\section{DAFTAR PUSTAKA}

1. WHO, 2014. Global Tuberculosis Report 2014. World Health Organization, 20 Avenue Appia, 1211 Geneva, Geneva. doi:10.1371/journal. pmed.1001270)

2. Kartasasmita, C.B., 2009. Setiap Menit Muncul Penderita Tuberkulosis Baru. Fajar Kesehatan, vol.6, 17 Juli 2009 
3. Muslih, Lukmono, Suhartono, Suwondo, Martini. Faktor-Faktor yang Berpengaruh terhadap Kejadian Tuberkulosis pada Wanita (Studi Kasus di RSUD Kabupaten Brebes), Jurnal Epidemiologi Kesehatan Komunitas 3 (1), 2018, 48-53

4. Profil Kesehatan Propinsi Jawa Timur Tahun 2016

5. Profil Kesehatan Propinsi DKI, Tahun 20016

6. Yusuf, I., Jusuf, A., Sjahrurrahman, A., 2005. Tuberkulosis dalam Kurikulum Pendidikan Dokter Berbasis Kompetensi. Fakultas kedokteran se-Indonesia bekerjasama dengan Departemen Kesehatan R.I, Jakarta.

7. Astawan M. 2009. Ikan gabus dibutuhkan pascaoperasi [internet]. [diunduh 2011 April 28]. Tersedia pada: http://cybermed. cbn.net.id

8. Chin, J., Kandun, I.Nyoman, 2006. Manual Pemberantasan Penyakit Menular. C.V. Infomedika, Jakarta.
9. Cook, G.C., Zumla, A.I., 2009. Tuberculosis, in: Manson's Tropical Disease. Saunders Elsevier, ISBN: 978-14160-4471-0, London, pp. 983-1004

10. Gani, A., 2008. Metode Bakteriologi Diagnostik. Balai Besar Laboratorium Kesehatan Propinsi Sulawesi Selatan, Makassar.

11. Kays, M.B., Koda-kimble, M.A., Alldredge, B.K., Corelli, R.L., Guglielmo, B.J., Kradjan, W.A., Williams, B.R., 2009. Tuberculosis, in: Applied Therapeutics : The Clinical Use of Drugs Pathogenesis. Lippincott Williams and Wilkins, Philadelphia, Pennsylvania USA, pp. 1736-1761.

12. Kemenkes R.I, 2011. Pedoman Nasional Pengendalian Tuberkulosis. Direktorat Jenderal Pengendalian Penyakit dan Penyehatan Lingkungan, Edisi 2, Cetakan tahun 2011, Jakarta.

13. Amanda J. Meyer, Collins Atuheire, William Worodria, Samuel Kizito , Achilles Katamba , Ingvar Sanyu , Alfred Andama, Irene Ayakaka , Adithya 
Cattamanchi, Freddie Bwanga, Laurence

Huang, J. Lucian Davis, Sputum quality

and diagnostic performance of GeneXpert

MTB/RIF among smear-negative adults

with presumed tuberculosis in Uganda,

https://journals.plos.org/plosone/article/

file?id=10.1371/journal. pone. 0180572

14. Susilo, Dwi, Pengetahuan Wanita Usia

Subur dengan Kepatuhan berobat Paru.,

Oksitosin, Kebidanan, Vol. 1, No. 1,

Februari 2014; 31-34

15. Nurkumalasari, Dian Wahyuni, Nurnaningsih, Hubungan Karakteristik

Penderita Tuberculosis Paru dengan Hasil

Pemeriksaan Dahak di Kabupaten Ogan

Ilir., Jurnal Keperawatan Sriwijaya, Vol. 3,

No. 2, Juli 2016

16. Budi, I.S., Damayanti, N.A., Wulandari, R.D., 2012. Kontribusi Koordinasi terhadap Penemuan Suspek Tuberkulosis Paru di Kabupaten Madiun. J. Manaj. Pelayanan Kesehat. 15, 7-11.

17. Munthe, B., 2009. Disain Pembelajaran. Pustaka Insan Madani, Yogyakarta.
18. Nasution, 2010. Berbagai Pendekatan dalam Proses Belajar Mengajar. Bumi Aksara, Jakarta.

19. Probandari, A., Utarini, A., Lindholm, L., Hurtig, A., 2011. Social Science \& Medicine Life of a Partnership: The Process of Collaboration between the National Tuberculosis Program and the Hospitals in Yogyakarta, Indonesia. Soc. Sci. Med. 73, 1386-1394. doi:10.1016/j.socscimed.2011.08.017

20. Moedjiharto TJ. 2007. Ikan sebagai bahan substitusi human serum albumin (HSA) dalam penyumbang biofarma Indonesia [internet]. [diunduh 2011 April 28]. Tersedia pada: http://oldprasetya.ub.id.

21. Muchtadi D. 2010. Teknik Evaluasi Nilai Gizi Protein. Bandung (ID): Penerbit Alfabeta

22. Adi AC. 2010. Efikasi pemberian makanan tambahan (PMT) biskuit diperkaya dengan tepung protein ikan lele dumbo (Clarias gariepinus), isolate 
Jurnal IImiah Respati

$\begin{array}{llll}\text { protein kedelai dan probiotik } & \text { tahun) berat badan rendah [disertasi]. } \\ \text { Enterococcus faecium IS-27526 yang } & \text { Bogor (ID): Sekolah Pascasarjana, Institut } \\ \text { dimikroenkapsulasi pada balita }(2-5 & \text { Pertanian } & \text { Bogor. }\end{array}$

